\title{
ADAPTIVE MANAGEMENT PLAN \\ FOR SENSITIVE PLANT SPECIES \\ ON THE NEVADA TEST SITE
}

March 2001

\section{Prepared by \\ Bechtel Nevada}

Ecological Services

P.O. Box 98521

Las Vegas, NV 89193-8521 


\section{DISCLAIMER STATEMENT}

Reference herein to any specific commercial product, process, or service by trade name, trademark, manufacturer, or otherwise, does not necessarily constitute or imply its endorsement, recommendation, or favoring by the U.S. Government or any agency thereof or its contractors or subcontractors.

\section{AVAILABILITY STATEMENT}

Available for sale to the public from:

U.S. Department of Commerce

National Technical Information Service

5285 Port Royal Road

Springfield, VA 22161-0002

Telephone: 800-553-6847

Fax: 703-605-6900

E-mail: orders@ntis.fedworld.gov

Online ordering: http://www.ntis.gov/ordering.htm

Available electronically at http://www.doe.gov/bridge

Available for a processing fee to the U.S. Department of Energy and its contractors, in paper, from:

U.S. Department of Energy

Office of Scientific and Technical Information

P.O. Box 62

Oak Ridge, TN 37831-0062

Telephone: 865-576-8401

Fax: 865-576-5728

E-Mail: reports@adonis.osti.gov 


\section{ADAPTIVE MANAGEMENT PLAN \\ FOR SENSITIVE PLANT SPECIES}

\section{ON THE NEVADA TEST SITE}

March 2001

WORK PERFORMED UNDER

CONTRACT NO. DE-AC08-96NV11718

Prepared for the

U.S. Department of Energy

Nevada Operations Office

Environment, Safety, and Health Division

P.O. Box 98518

Las Vegas, NV 89193-8518

Prepared by

\section{Bechtel Nevada}

Ecological Services

P.O. Box 98521

Las Vegas, NV 89193-8521 
THIS PAGE IS INTENTIONALLY LEFT BLANK 


\section{CONTENTS}

ACRONYMS AND ABBREVIATIONS $\ldots \ldots \ldots \ldots \ldots \ldots \ldots \ldots \ldots \ldots \ldots \ldots$

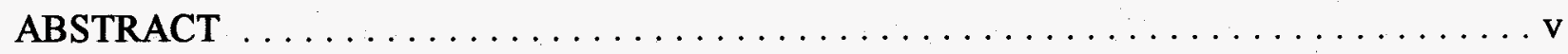

1.0 INTRODUCTION $\ldots \ldots \ldots \ldots \ldots \ldots \ldots \ldots \ldots \ldots \ldots \ldots \ldots \ldots \ldots \ldots$

2.0 SPECIES TO BE MONITORED $\ldots \ldots \ldots \ldots \ldots \ldots \ldots \ldots \ldots \ldots \ldots \ldots$

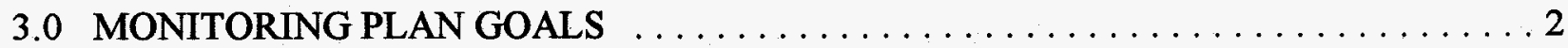

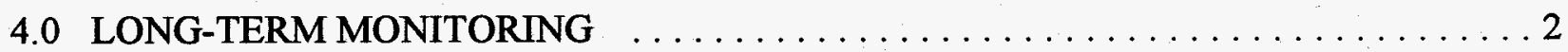

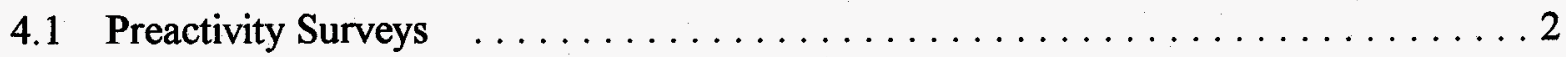

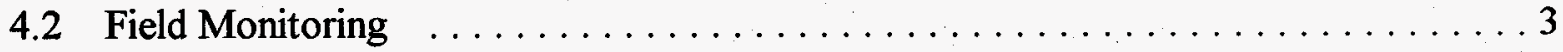

5.0 OTHER MANAGEMENT ACTIONS $\ldots \ldots \ldots \ldots \ldots \ldots \ldots \ldots \ldots \ldots \ldots \ldots$

5.1 Actions for DOE/NV Related Impacts $\ldots \ldots \ldots \ldots \ldots \ldots \ldots \ldots \ldots \ldots$

5.2 Actions for Non-DOE/NV Related Impacts $\ldots \ldots \ldots \ldots \ldots \ldots \ldots \ldots \ldots \ldots$

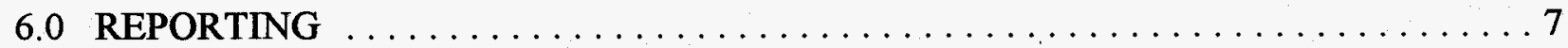

7.0 LITERATURE CITED $\ldots \ldots \ldots \ldots \ldots \ldots \ldots \ldots \ldots \ldots \ldots \ldots \ldots \ldots \ldots$

DISTRIBUTION $\ldots \ldots \ldots \ldots \ldots \ldots \ldots \ldots \ldots \ldots \ldots \ldots \ldots \ldots$

\section{List of Tables}

Table 1. Management actions taken to mitigate significant disturbances to sensitive NTS plant species 
THIS PAGE IS INTENTIONALLY LEFT BLANK 


\section{ACRONYMS AND ABBREVIATIONS}

DOE/NV

ESA

FWS

GIS

NNHP

NTS
U.S. Department of Energy, Nevada Operations Office

Endangered Species Act

U.S. Fish and Wildlife Service

Geographic Information System

Nevada Natural Heritage Program

Nevada Test Site 
THIS PAGE IS INTENTIONALLY LEFT BLANK 


\begin{abstract}
The Nevada Test Site supports numerous plant species considered sensitive because of their past or present status under the Endangered Species Act and with federal and state agencies. In 1998, the U.S. Department of Energy, Nevada Operations Office (DOE/NV) prepared a Resource Management Plan which commits to protect and conserve these sensitive plant species and to minimize cumulative impacts to them. This document presents the procedures of a long-term adaptive management plan which is meant to ensure that these goals are met. It identifies the parameters that are measured for all sensitive plant populations during long-term monitoring and the adaptive management actions which may be taken if significant threats to these populations are detected. This plan does not, however, identify the current list of sensitive plant species known to occur on the NTS. The current species list and progress on their monitoring is reported annually by DOE/NV in the Resource Management Plan.
\end{abstract}


THIS PAGE IS INTENTIONALLY LEFT BLANK 


\subsection{INTRODUCTION}

The Nevada Test Site (NTS) supports numerous plant species considered sensitive because of their past or present status under the Endangered Species Act (ESA) and with federal and state agencies. The classifications have identified them as species whose continued existence may be at risk due to the following factors: limited geographic distributions, threatened habitats or ranges, over-utilization, disease or predation, inadequate regulatory mechanisms for their protection, and other natural or man-made factors. Over the last three decades, the U.S. Department of Energy, Nevada Operations Office (DOE/NV) has taken an active role in collecting information on the status of these sensitive plants and produced numerous documents reporting their occurrence, distribution, and susceptibility to threats on the NTS (Beatley 1977a; 1977b; Rhoads and Williams 1977; Rhoads et al. 1978, 1979a, 1979b; Cochrane 1979; Sauls et al. 1980; Collins and O'Farrell 1984; EG\&G/Energy Measurements, Inc. [EG\&G/EM] 1988; Blomquist et al. 1992; Blomquist et al. 1995; Anderson 1998). Data collected on the NTS have been invaluable to the U.S. Fish and Wildlife Service (FWS) and state agencies in determining if species should be protected.

In 1998, DOE/NV prepared a resource management plan (DOE 1998) which identifies two goals related to all sensitive species on the NTS. They are to protect and conserve sensitive species, and minimize cumulative impacts to them. This monitoring plan was developed to ensure that these goals are being met. This plan identifies the parameter(s) which will be measured for sensitive plant populations and the various adaptive management actions which may be taken if significant threats to the plants are detected.

\subsection{SPECIES TO BE MONITORED}

Monitoring will be conducted for all sensitive plants known to occur on the NTS. Sensitive plants are those with some level of federal and/or state status. The "Sensitive Plant List" (Sensitive List), "Plant and Animal Watch List" (Watch List), and "Detailed Rare Plant List" (Detailed List) maintained by The Nevada Natural Heritage Program (NNHP) will be used to annually update the list of sensitive species to be monitored. These NNHP lists report the current status of plants assigned by both federal agencies (FWS, U.S. Bureau of Land Management, U.S. Forest Service) and state agencies (Nevada Division of Forestry, NNHP, and the Northern Nevada Native Plant Society).

When a plant appears on either the NNHP Sensitive List or Watch List, existing publications on NTS plants and herbarium records from the NTS and the University of Nevada, Las Vegas will be searched. If the plant is known or suspected to occur on the NTS, then the plant will be added to the monitoring plan. A fact sheet will be written for each species and will describe the currently known habitat, distribution, and abundance of the species on and off the NTS. It will identify areas of suitable habitat on the NTS where field surveys should be conducted to locate the species if more distribution data is needed. If necessary, field surveys will then be conducted to adequately describe the species' habitat, NTS distribution and abundance, and to determine the species' susceptibility to threats. All information gathered will be published and shared with 
federal and state natural resource agencies. Once a species' status on the NTS has been determined, long-term monitoring of the species will be initiated.

\subsection{MONITORING PLAN GOALS}

The primary goal of monitoring is to ensure that impacts caused directly by NTS projects can be detected, quantified, and managed so that the species' occurrence on the NTS is not threatened by such projects. These direct impacts are identifiable from project descriptions and are generally limited to loss of habitat during construction. A secondary goal of this plan is to detect nonDOE/NV threats and identify steps that may be taken to prevent the demise of a sensitive species on the NTS due to such threats.

\subsection{LONG-TERM MONITORING}

Long-term monitoring will consist of two activities: 1) preactivity surveys at new project sites and 2) periodic monitoring of sensitive plant locations on the NTS. Preactivity surveys are conducted to assess the direct impacts of land disturbance, and periodic monitoring is conducted to assess indirect impacts.

\subsection{Preactivity Surveys}

Preactivity surveys are performed by biologists at proposed project sites where land disturbance will occur. The goal is to document the presence of any sensitive species and to make recommendations which would minimize adverse effects to the species and their associated habitat. Rarely do project sites disturb the known locations of sensitive plants. This is due mainly to the disparity between the preferred habitats of the sensitive plants and preferred construction sites. Since the early 1980 's, no known population of sensitive plant has been significantly disturbed by construction activities. The locations of all projects which will disturb land and for which preactivity surveys are conducted are documented in a Geographic Information System (GIS) database. This database will be used to monitor the cumulative impacts of habitat loss within various vegetation associations and population ranges of sensitive species.

The locations of all sensitive plant locations on the NTS have also been entered into a GIS database. GIS analysis software (ArcView) will be used to report the number of plant locations that are within a prescribed radius of land-disturbing projects for which surveys have been conducted since the late 1970's. The total number of plant locations, by species, which contain or are adjacent to a new disturbance, will be tracked. A new disturbance is defined as any project that was not present at the time the plant location was first found.

If a single known plant location will be significantly disturbed by a new project, then other management actions will be initiated. These actions may range from merely documenting the disturbance to initiating protective measures such as restricting land access to other plant locations or plant reintroduction (see Section 5.0). 


\subsection{Periodic Monitoring}

Some sensitive plant species may have limited numbers $(<10)$ of known locations on the NTS All locations for these plants will be monitored at least once during a five-year period. For other species with larger numbers of known locations, a subsample of 5 - 10 locations will be monitored in a single season at least once every five years. For each species, the $5-10$ locations chosen to sample may not be the same from sampling period to sampling period, and some locations may never be routinely sampled. The intent will be to sample locations where it is also most likely to detect direct effects of NTS activities and effects of other biotic and abiotic factors such as drought, herbivory, or disease occurring within an ecoregion.

Field monitoring for each species will occur during the period of peak production. At each location the following data will be collected to assess the health of the local population: local abundance (as a subjective category); evidence of reproduction; evidence of herbivory, disease, or direct disturbance; and estimated number of plants within specific phenological stages. Also, the proximity to the nearest known land disturbances will be recorded to verify or correct the existing geospatial data linking disturbed land coverages with plant location coverages. The work instruction which details the data collection procedures will be followed and updated periodically.

If at any time during field monitoring a single location is found to be significantly impacted by a direct disturbance, then further management actions will be taken. These may include initiating more intensive (e.g., annual) field monitoring of remaining locations of the species, fencing, or other site-specific mitigation actions (see Section 5.0) If a significant decrease in plant abundance or reproductive effort is observed then the location may be sampled more frequently. A speciesspecific study design will be developed and implemented to determine the causal factor(s). Frequent sampling of this location will continue until it can be verified that the local plant population is still present and viable or is no longer present. Table 1 summarizes the conditions under which actions beyond long-term monitoring will occur and what these actions may be.

The significance of observed direct impacts and plant population conditions will be determined based on best professional judgement. In general, a significant impact or condition will be one which threatens the continued existence of a sensitive plant at a known location and which may eventually threaten its continued existence on the NTS. The threshold for significance will therefore differ among species.

\subsection{OTHER MANAGEMENT ACTIONS}

\subsection{Actions for DOE/NV Related Impacts}

If a sensitive plant population is found within a project site during a preactivity survey, recommendations will be made to alter the project to avoid it or minimize disturbance to it. A post-activity survey to document the status of the plant population will be conducted when construction is completed. If the population was avoided, long-term monitoring of the species will continue according to schedule. 
If all or a portion of the local population was disturbed at a location, annual monitoring of the location will be initiated and will continue until it is determined that the population was extirpated or is stable and not threatened. Periodic long-term monitoring will then resume. If the entire local population appears to have been destroyed, then other NTS locations of the same species will be monitored annually starting at the next plant flowering/seeding period. Annual monitoring will cease after five years, or sooner, if an adequate assessment of the population's health and susceptibility to threats at remaining locations can be made. Periodic long-term monitoring will then be resumed for the species.

If remaining population locations need protection, fences or stay-out signs may be erected. Project planning and siting procedures and the preactivity survey process will be reviewed to ensure that future significant impacts to sensitive plants are avoided. Also, if the plant no longer occurs at the project site, biologists will consider re-introducing the species (via seeds or transplants) into suitable habitat adjacent to the project site. A study design would be developed which would include annual monitoring of the location for five years to document population status.

If during periodic monitoring, a significant impact is observed which is believed to be NTS project-related, then the actions discussed above may be taken. A summary listing of all actions which may be taken to mediate DOE/NV related impacts are shown in Table 1.

\subsection{Actions for Non-DOE/NV Related Impacts}

If a significant decrease in population size or reproductive success is observed at one or more locations during periodic monitoring, investigative actions will be taken. Decreases in these measures will be determined significant based on comparisons with historic species-specific data and best professional judgement. If no observable land-disturbing or NTS project-related activity appears to be the cause of the significant impact, the following actions will be taken.

- A field study will be designed to determine the causal factor(s) of the population decline. Suspected causal factors may include climate, herbivory, and disease.

- Annual monitoring of the affected location(s) will be initiated to collect biotic or abiotic data to identify causal factors. The field study will be conducted until the causal factor(s) are identified or until the viability of local populations improve.

- If wildfire impacts a local population, it will be documented, and annual surveys of the affected plant location(s) will be conducted for at least three years. Periodic long-term monitoring (i.e., once every five years) will resume once it is determined that the population is stable or if no plants have returned to the site after five consecutive years of monitoring. 
Table 1. Management actions taken to mitigate significant disturbances to sensitive NTS plant species

\section{CONDITION}

ACTION

A. No significant reduction in plant abundance or reproductive effort observed during periodic field monitoring or post-activity survey

Continue long-term monitoring of sample locations every five years

B. Plant population found within project area during a preactivity survey

1. Make recommendations to avoid population.

2. Conduct post-activity survey to document impact of project

C. Significant land disturbance or project-related disturbance observed during field monitoring or post-activity survey
1. Initiate annual monitoring of disturbed location to document long-term impact of disturbance. Resume periodic long-term monitoring when population appears stable.

2. Eliminate location from long-term monitoring if plants no longer present.

3. Monitor additional plant locations annually for no more than five years to re-assess susceptibility to threats at other known locations.

4. Protect other known locations if necessary from similar disturbance. Consider fencing and/or posting signs to identify other locations in the field to avoid.

5. Assess cause of significant disturbance (e.g., non-adherence to preactivity survey recommendations, conducting activity w/o prior preactivity survey) and alter preactivity survey procedures to prevent occurrence at other locations.

6. Re-introduce sensitive species to location if prudent and reasonable, and monitor annually for next five years to document status, then re-initiate long-term monitoring. 
Table 1. (Continued)

\section{CONDITION}

D. Significant reduction in plant abundance or reproductive effort observed during field monitoring. Does not appear to be project-related.

\section{ACTION}

1. Design field study to collect additional data necessary to determine causal factors.

2. Initiate annual monitoring of location and continue until causal factors determined or viability of local population improves, then resume periodic long-term monitoring.

3. Implement mitigation measures as determined necessary. Examples include:

Climatic causal factors

- Irrigate or increase water harvesting at location if necessary and monitor annually to determine effect of mitigation.

- Resume periodic long-term monitoring once climatic conditions change.

Wildfire causal factor

- Initiate annual monitoring of location for at least three years.

- Resume periodic long-term monitoring of location if population appears stable or plant is absent for five consecutive years.

Herbivory causal factor

- Develop and implement a plan to protect the species from herbivory at the location and other known locations if necessary.

Disease causal factor

- Develop and implement a plan to protect the species from disease at the location and other known locations if necessary. 
- If the causal factor(s) are identified, a mitigation action plan will be developed to identify reasonable and prudent actions to be taken to lessen or eliminate the impact and ensure the continued existence of the species on the NTS. It is unlikely that such plans will be necessary given the continued occurrence of these plants on the NTS over the past three decades.

\subsection{REPORTING}

The results of long-term monitoring and any adaptive management actions taken during a fiscal year will be reported in the annual progress report for all Environmental Monitoring and Compliance Program tasks.

\subsection{LITERATURE CITED}

Anderson, D. C. 1998. Distribution of Clokey's Eggvetch (Astragalus oophorus var. clokeyanus) on the Nevada Test Site. DOE/NV/11718-262, Bechtel Nevada, Las Vegas, NV, December 1998.

Beatley, J. C. 1977a. Endangered plant species of the Nevada Test Site, Ash Meadows, and centralsouthern Nevada. COO-2307-11, U. S. Energy Research and Development Administration, Nevada Test Site, NV.

Beatley, J. C. 1977b. Threatened plant species of the Nevada Test Site, Ash Meadows, and centralsouthern Nevada. COO-2307-12, U. S. Energy Research and Development Administration, Nevada Test Site, NV.

Blomquist, K. W., C. A. Wills, W. K. Ostler, K. R. Rautenstrauch, and T. P. O'Farrell. 1992. Distribution, life history, management, and current status of Astragalus beatleyae on the U.S. Department of Energy's Nevada Test Site. EG\&G/EM Santa Barbara Report No. 10617-2187.

Blomquist, K. W., T. A. Lindermann, G. E. Lyon, D. C. Steen, C. A. Wills, S. A. Flick, and W. K. Ostler. 1995. Current distribution, habitat, and status of Category 2 Candidate plant species on and near the U.S. Department of Energy's Nevada Test Site. EG\&G/EM Las Vegas Area Operations Report No. 11265-1149.

Cochrane, S. 1979. Status of endangered and threatened plant species on Nevada Test Site - a survey. Parts 1 and 2. Appendix C: Collection records for the taxa considered. EG\&G/EM Santa Barbara Report No. 1183-2356.

Collins, E. and T. P. O'Farrell. 1984. Surveys for plant species of concern on northern and eastern Yucca Flat, Nevada Test Site, Nye County, Nevada. EG\&G/EM Santa Barbara Report No. 10282-2039.

DOE (U.S. Department of Energy), 1998. Nevada Test Site Resource Management Plan, DOE/NV-518, U.S. Department of Energy, Nevada Operations Office, Las Vegas, NV, December 1998. 
EG\&G Energy Measurements. 1988. Nevada Test Site Area Map: Distribution of known populations of Astragalus beatleyae and Penstemon pahutensis on the Nevada Test Site and Nellis Bombing Range, prepared for the U.S. Department of Energy, Nevada Operations Office, Las Vegas, NV.

Rhoads, W. A. and M. P. Williams. 1977. Status of endangered and threatened plant species on Nevada Test Site - a survey. Part 1: endangered species. EG\&G/EM Santa Barbara Report No. 1183-2356.

Rhoads, W. A., S. Cochrane, and M. P. Williams. 1978. Status of endangered and threatened plant species on Nevada Test Site - a survey. Part 2: threatened species. EG\&G/EM Santa Barbara Report No. 1183-2356.

Rhoads, W. A., S. Cochrane, and M. P. Williams. 1979a. Addendum to status of endangered and threatened plant species on Nevada Test Site - a survey. Parts 1 and 2. EG\&G/EM Santa Barbara Report No. 1183-2356.

Rhoads, W. A., S. Cochrane, and M. P. Williams. 1979b. Status of endangered and threatened plant species on Tonopah Test Range - a survey. EG\&G/EM Santa Barbara Operations Report No. 1183-2387.

Sauls, M. L., T. P. O'Farrell, and W. A. Rhoads. 1980. The plant species Astragalus beatleyae on the Nevada Test Site. Unpublished U.S. Department of Energy Topical Report, EG\&G Santa Barbara Operations Report No. 1183-2412. 


\section{DISTRIBUTION}

U.S. Department of Energy, Nevada Operations Office

Las Vegas, Nevada

Robert Furlow, ESH (6)

Public Reading Facility

Technical Information Resource Center

U.S. Department of Energy,

Yucca Mountain Site Characterization Office

Las Vegas, Nevada

Scott Wade

U.S. Bureau of Land Management

Las Vegas, Nevada

Mark Morse

U.S. Fish and Wildlife Service, Suboffice No. 1

Las Vegas Field Office

Las Vegas, Nevada

Assistant Field Supervisor (3)

Desert National Wildlife Refuge Complex

Las Vegas, Nevada

Richard Birger

Nellis Air Force Range

Las Vegas, Nevada

Susan Barrow

Nevada Division of Forestry

Las Vegas, Nevada

John Jones

Bechtel Nevada

Environmental Monitoring

North Las Vegas, Nevada

Don Van Etten (8)

University of Nevada Las Vegas,

Harry Reid Center for Environmental Studies

Las Vegas, Nevada

Don Baepler
Nevada Natural Heritage Program

Carson City, Nevada

Glenn Clemmer

The Nature Conservancy

Las Vegas, Nevada

James Moore

DOE Office of Scientific and Technical Information

Oak Ridge, Tennessee (1) electronic 